\begin{tabular}{c|c|c}
\hline \hline Vol. 248: 125-139, 2003 & MARINE ECOLOGY PROGRESS SERIES \\
Mar Ecol Prog Ser & Published February 20 \\
\hline
\end{tabular}

\title{
Low rates of predation on planktonic marine invertebrate larvae
}

\author{
Kevin B. Johnson ${ }^{1, *}$, Alan L. Shanks ${ }^{2}$ \\ ${ }^{1}$ Department of Marine and Environmental Systems, Florida Institute of Technology, 150 West University Blvd., Melbourne, \\ Florida 32901, USA \\ ${ }^{2}$ Oregon Institute of Marine Biology, University of Oregon, PO Box 5389, Charleston, Oregon 97420, USA
}

\begin{abstract}
We conducted in situ observations and experiments to evaluate predation on invertebrate larvae in near-natural plankton assemblages captured in large-volume in situ corrals. In these captured assemblages, we placed known numbers of marked larvae and determined their fate after $24 \mathrm{~h}$. Recovery of marked larvae averaged $99 \%( \pm 0.25 \%, \mathrm{SE})$, enabling a thorough and direct determination of predators and predation rates. The highest predation rate observed was on bivalve veligers by the heterotrophic dinoflagellate Noctiluca scintillans (7\% lost in 24 h). Gastropod veligers experienced no predation and echinoplutei experienced only rare predation. While N. scintillans preyed on bivalve veligers in some runs, most runs yielded little or no predation. These observations suggest that larvae can encounter relatively safe assemblages. To investigate low predation, corral experiments were conducted which presented prey at near-natural and unnaturally high densities and in the presence or absence of natural background plankton. Predation observed at high prey densities decreased or disappeared at near-natural prey densities. This suggests that low encounter rates may explain some of the low predation. Predation rates also decreased in the presence of natural background plankton. Background plankton may occupy the predator's time and decrease opportunities for encounters with larvae, obscure larvae from detection or capture, or serve as substitute food. Since predation was usually low or absent in diverse corral assemblages, we recommend confirming natural relationships and predation rates for suspected predator-prey combinations before making assumptions about predator effects. It may frequently be the case that planktonic larvae suffer little or no predation by planktonic predators.
\end{abstract}

KEY WORDS: Noctiluca $\cdot$ Plutei $\cdot$ Veligers $\cdot$ Larval mortality $\cdot$ Planktonic predation

Resale or republication not permitted without written consent of the publisher

\section{INTRODUCTION}

Many benthic marine invertebrates produce planktonic larvae that reside in the water column for hours to months. These larvae develop in the plankton until competent to settle and metamorphose. The number of competent larvae present in the plankton often correlates with recruitment to benthic communities (Gaines et al. 1985), highlighting the important relationship between planktonic larval supply and benthic community composition.

A single adult can produce vast numbers of these planktonic propagules. For example, during 1 spawning season the sand dollar Dendraster excentricus can

${ }^{*}$ Email: johnson@fit.edu spawn $3.8 \times 10^{5}$ eggs (Morris et al. 1980), the Dungeness crab Cancer magister can release $2.5 \times 10^{6}$ larvae (Morris et al. 1980), the oyster Crassostrea gigas can spawn $55.8 \times 10^{6}$ eggs (Galtsoff 1964), and the sunflower star Pycnopodia helianthoides may release as many as $160 \times 10^{6}$ eggs (Chia \& Walker 1991). Relatively few of these propagules, however, ultimately recruit to any adult community due to low fertilization (e.g. Pennington 1985) and/or high mortality between fertilization and recruitment (Thorson 1950). Some studies have estimated mortality rates by contrasting propagule production with benthic recruitment (reviewed in Rumrill 1990). These studies have estimated 
variable population mortality rates, ranging from $0.03 \mathrm{~d}^{-1}$ in the cone snail Conus quercinus (Perron 1986) to $0.80 \mathrm{~d}^{-1}$ in the clam Mya arenaria (Ayers 1956). Most often it is unknown whether larval predation or some other factor (fertilization failure, embryo inviability, starvation, unfavorable transport, early post-settlement mortality, etc.) is responsible for propagule loss. Strathmann (1985) points out that these types of estimates include unverified assumptions and biases of unknown magnitude. Nonetheless, loss in the plankton is apparently high and our current knowledge of the causes of this mortality is limited.

This study describes field observations and manipulative experiments investigating and quantifying planktonic predation on larvae. All observations and experiments were conducted under the most natural conditions that could be arranged. Replicated in situ observations were designed to observe predation, identify predators, and estimate potential predation rates. Subsequent empirical field experiments, in which background plankton and prey densities were manipulated, were also conducted.

Novel methods make this study uniquely applicable as a gage of predation risk for the meroplanktonic larvae tested. We employed natural plankton assemblages, including a diverse suite of potential predators and alternative prey. Experiments and observations took place in large-volume corrals, reducing potential container artifacts. Corrals were inoculated with a known number of marked larvae at natural densities. Marking of larvae enhanced retrieval, survivorship determination, and predator identification. Finally, observations of larvae were direct, leaving no doubt as to the fate of larvae.

\section{MATERIALS AND METHODS}

Marked larvae. Marked prey included plutei of the sand dollar Dendraster excentricus ( 300 $\mu \mathrm{m}$ in length), veligers of the snail Littorina plana ( 150 to $200 \mu \mathrm{m}$ in length), and D-hinge veligers of the oyster Crassostrea gigas $(\sim 110 \mu \mathrm{m}$ in length). Adult $D$. excentricus breeding stock were collected from the North Spit, Coos Bay, Oregon, and from West Sound, Orcas Island, Washington. Adult L. plana were collected from Sunset Bay, Oregon and Friday Harbor, Washington. Gastropod and echinoid embryos were obtained using spawning and culture methods described in Strathmann (1987). D-hinge larvae of the oyster C. gigas were donated by Whiskey Creek Oyster Farms (Tillamook, Oregon).

Larvae were marked with Calcein (Sigma), which is permanently incorporated into skeletons as calcium carbonate is laid down. Calcein fluoresces when illu- minated by UV light and viewed through a fluorescein isothiocyanate (FITC) filter. Larvae were cultured in filtered seawater on diets of Isochrysis galbana and Rhodomonas sp. in the presence of Calcein at a concentration of 200 to $500 \mathrm{ppm}$. Cultured under these circumstances, behavior and development of these larvae (K. B. Johnson pers. obs.) and others (R. J. Rowley unpubl.) appear normal. Calcein-treated skeletons retain their fluorescence and were visible in the guts of predators and in fecal pellets over the course of these experiments. In preliminary feeding trials, we fed marked larvae to a variety of predators to determine whether Calcein influences palatability or vulnerability. Under unnatural laboratory conditions, with high prey densities in filtered seawater, Calcein did not appear to influence predation by brachyuran zoeae, cumaceans, polychaete larvae, hydromedusae, or copepods (i.e. when these predators consumed unmarked larvae, they also consumed marked larvae at comparable rates).

Corrals, deployment, and collection. Observations and experiments were conducted in corrals made of clear flexible 20 mil PVC sheeting (Fig. 1). Corrals were $0.38 \mathrm{~m}$ diameter by $1.29 \mathrm{~m}$ tall and held approx. 1231 of seawater when deployed (Fig. 1D); they were water-tight except for the cod-end collection buckets. Each bucket had 8 portholes covered with $53 \mu \mathrm{m}$ Nitex mesh (total filtering area of $176 \mathrm{~cm}^{2}$ ). For deployment, we collapsed corrals longitudinally and fastened them in the collapsed position with a line (Fig. 1A). Corrals were then submerged and lowered to a depth of $\sim 1 \mathrm{~m}$ (Fig. 1A) with a 3-point bridle, harness and line. After the disturbed water column above the collapsed corral had drifted away, the securing line was released (Fig. 1B) and the mouth of the corral was drawn slowly surfaceward (Fig. 1C) to break the surface of the water. During the observations and experiments, corral mouths were suspended $30 \mathrm{~cm}$ above the water's surface by floats tethered to a dock. Currents did not distort corral shape or volume. This deployment technique resulted in the gentle capture and isolation of a natural assemblage of plankton and potential predators (see 'Results'), including delicate predators such as chaetognaths and coelenterates. The majority of predators involved in this study were captured in this manner, with no fluid sheer or suction that might subtly injure delicate predators and render them ineffective.

Observational and experimental runs lasted $24 \mathrm{~h}$, an attempt to balance the advantages of longer vs shorter time. Longer time periods are desirable to allow predators and prey time to interact. However, after 2 or more days, the abundance and composition of background plankton, especially protists, can begin to change dramatically in a relatively small closed system. Background plankton is known to have a profound effect on 


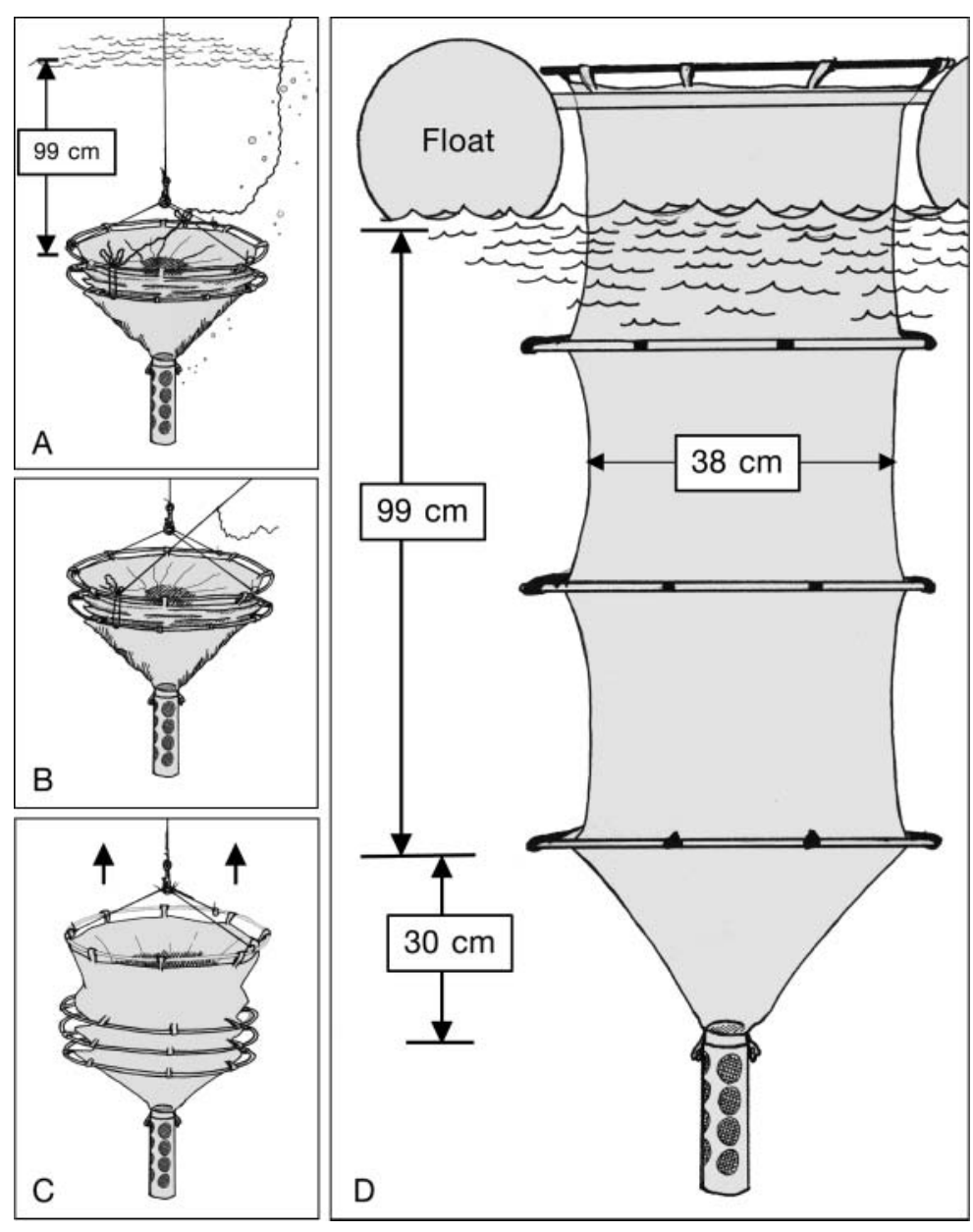

Fig. 1. In situ corrals: deployment and dimensions. (A) Collapsed corral lowered to depth; (B) corral released for expansion; (C) gentle capture of natural plankton assemblage; (D) deployed corral suspended from floats.

Corral volume approx. 1231 predation rates (Johnson \& Brink 1998) and this was behind our choice to limit observations to $24 \mathrm{~h}$. At the close of experiments, corrals were hauled from the sea and corral water exited through the codend bucket. Contents were fixed immediately in $4 \%$ buffered formalin. Filter screens were washed repeatedly to free plankton from the mesh and ensure collection of the whole sample. Samples were stored in the dark to protect against the possibility of light degradation of the fluorescent marking.

In situ observations. One run of in situ observations consisted of 4 corrals deployed concurrently and inoculated with known numbers of marked larvae. A total of 10 runs (i.e. 40 corrals) were conducted, 2 in the boat basin at Coos Bay, Charleston, Oregon $\left(43^{\circ} 21^{\prime} 10^{\prime \prime} \mathrm{N}, 124^{\circ} 19^{\prime} 50^{\prime \prime} \mathrm{W}\right)$, and 8 from the dock of Friday Harbor Laboratories, Friday Harbor, Washington $\left(48^{\circ} 32^{\prime} 10^{\prime \prime} \mathrm{N}\right.$, $\left.123^{\circ} 00^{\prime} 19^{\prime \prime} \mathrm{W}\right)$. For some observation runs, ambient potential predators that were rare in the plankton were added to corrals. These potential predators were seeded to ensure replicated representation in the corrals. Table 1 provides a summary of run location, light conditions during the start of the experiment (day vs night), numbers of marked larvae added, and the identities and numbers of seeded potential predators. Day runs were started between 09:00

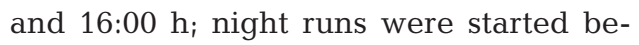
tween 22:00 and 01:00 h. For a single run,

Table 1. Summary of in situ observations. Runs were conducted at Coos Bay (CB) or Friday Harbor (FH) and corrals were loaded either during the day (D) or night (N). In addition to randomly captured organisms, potential predators also included the following seeded animals: (a) the hydromedusa Proboscidactyla flavicirrata; (b) the hydromedusa Sarsia sp.; (c) the hydromedusa Aglantha

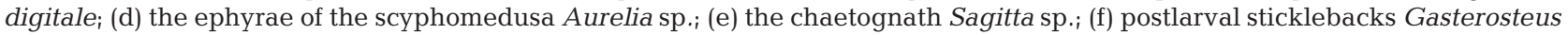
aculeatus ( $2 \mathrm{~cm}$ in length); (g) brachyuran zoeae; (h) anomuran zoeae; (i) trochophores of the polynoid polychaete Arctonöe vittata. Corral volume was 123 l. All 10 runs listed were replicated with 4 corrals each

\begin{tabular}{|c|c|c|c|c|c|c|c|}
\hline \multirow[t]{2}{*}{ Run } & \multirow{2}{*}{$\begin{array}{c}\text { Date } \\
\text { (mm/yy) }\end{array}$} & \multirow[t]{2}{*}{ Site } & \multirow{2}{*}{$\begin{array}{l}\text { Day/ } \\
\text { night }\end{array}$} & \multicolumn{3}{|c|}{ Marked prey (no. corral ${ }^{-1}$ ) } & \multirow{2}{*}{$\begin{array}{l}\text { Seeded potential } \\
\text { predators (no. corral }{ }^{-1} \text { ) }\end{array}$} \\
\hline & & & & $\begin{array}{l}\text { Echinoid } \\
\text { plutei }\end{array}$ & $\begin{array}{l}\text { Bivalve } \\
\text { veligers }\end{array}$ & $\begin{array}{c}\text { Gastropod } \\
\text { veligers }\end{array}$ & \\
\hline 1 & $04 / 96$ & $\mathrm{CB}$ & $\mathrm{D}$ & 100 & 100 & - & - \\
\hline 2 & $04 / 96$ & CB & $\mathrm{D}$ & 100 & - & - & - \\
\hline 3 & 07/96 & $\mathrm{FH}$ & $\mathrm{D}$ & 100 & 100 & - & - \\
\hline 4 & 07/96 & $\mathrm{FH}$ & $\mathrm{D}$ & - & 50 & 50 & $\mathrm{a}(2), \mathrm{b}(1)$ \\
\hline 5 & 08/96 & $\mathrm{FH}$ & $\mathrm{N}$ & 100 & 20 & 50 & $\mathrm{a}(2), \mathrm{e}(1)$ \\
\hline 6 & 08/96 & $\mathrm{FH}$ & $\mathrm{N}$ & 100 & 100 & - & $\mathrm{a}(2)$ \\
\hline 7 & $08 / 96$ & $\mathrm{FH}$ & $\mathrm{N}$ & 100 & 100 & - & a (1), c (1), e (4) \\
\hline 8 & 08/96 & $\mathrm{FH}$ & $\mathrm{D}$ & 100 & 100 & - & $f(2), d(3)$ \\
\hline 9 & 08/96 & $\mathrm{FH}$ & $\mathrm{D}$ & 50 & 50 & - & $\mathrm{d}(5), \mathrm{g}(5), \mathrm{h}(1)$ \\
\hline 10 & 08/96 & $\mathrm{FH}$ & $\mathrm{D}$ & 123 & 123 & - & a (2), d (2), g (3), h (1), i (2) \\
\hline
\end{tabular}


all replicates were loaded within 20 min of each other and collected exactly $24 \mathrm{~h}$ later in the same order.

After corrals were deployed, a known number of marked larvae were added to each corral. The densities of marked larvae in corrals were intended to reflect the upper range of natural densities. Our survey of the literature indicates that, for many invertebrate larvae, the experimental densities selected $\left(0.4\right.$ to $\left.1.0 \mathrm{l}^{-1}\right)$ are reasonable natural densities (Carriker 1951, Zimmerman 1972, Cameron \& Rumrill 1982, Rumrill et al. 1985, Emlet 1986, Miller 1995). Published field counts usually sample an integrated water column, either vertically or horizontally. For this reason, elevated densities of larvae due to patchiness or aggregation generally go undetected. Thus, our chosen densities, while high-end densities from the literature, are probably conservative high natural densities if patches predominate. Following inoculation, corral assemblages were mixed with an $8 \times 8$ inch $(20 \times 20 \mathrm{~cm})$ square plate, the center of which was attached to a plastic pole so it could be gently plunged through the water column of the corral.

When seeded predators were included (Table 1), they were collected at high tide by slowly towing a plankton net equipped with a large close-ended codend ('blind' cod-end, after Reeve 1981). Predators were quickly removed from the plankton sample using a large-bore pipette or a submerged cup, and isolated in filtered seawater. While viability of seeded predators could not be confirmed, they appeared intact and healthy when they were gently added to corrals. Runs began within $24 \mathrm{~h}$ of predator collection.

One predator, the trochophore larva of the scaleworm Arctonöe vittata, was obtained from culture. Adult specimens were collected from the rocky intertidal zone of San Juan Island, Washington. Individuals of $A$. vittata were spawned and larvae were cultured using methods described by Phillips \& Pernet (1996) with the addition of Coscinodiscus radiatus (CCMP 310 ) as a food source. Fertilized eggs were cultured in $600 \mathrm{ml}$ beakers at densities of $\sim 500$ ind. $\mathrm{l}^{-1}$. Approximately $21 \mathrm{~d}$ old larvae, exceeding $100 \mu \mathrm{m}$ in length, were used as predators.

The entire contents of each corral were sorted at 100x magnification with an epifluorescence microscope and an FITC filter. Marked larvae (prey) were tallied, fates were noted (i.e. it was determined whether fixed larvae were in predator guts or intact and apparently alive at the time of fixation), and predator identities were recorded. After the search for marked prey was complete, gut-content analysis was conducted on selected predators to identify and enumerate unmarked prey (i.e. prey organisms included with the natural assemblage captured in corrals).

Potential predators and background plankton in corrals were counted. In the case of relatively large potential predators $(>500 \mu \mathrm{m})$, the entire sample was counted. Background plankters, including small potential predators, wild invertebrate larvae, and potential alternative food items for predators, were counted in corral sample aliquots cut to one-quarter with a plankton splitter. Organisms counted in aliquots included large diatoms, dinoflagellates, small copepods $(<500 \mu \mathrm{m})$, copepod nauplii, barnacle nauplii, wild (unmarked) gastropod and bivalve veligers, and small polychaete larvae $(<500 \mu \mathrm{m})$.

Density and background experiments. Two corral experiments manipulating natural conditions were conducted from the dock at Friday Harbor Laboratories (Friday Harbor, Washington). The first experiment manipulated marked prey density and the presence of background plankton in order to determine whether the use of 'near-natural' densities (explained below) and background plankton might be responsible for the low observed predation. The 4 treatments were: (1) near-natural prey densities in 53- $\mu \mathrm{m}$-filtered seawater; (2) near-natural prey densities with background plankton (unfiltered seawater); (3) unnaturally high prey densities in 53- $\mu \mathrm{m}$-filtered seawater; (4) unnaturally high prey densities with background plankton (unfiltered seawater). Marked prey were Dendraster excentricus plutei and Crassostrea gigas veligers. The near-natural prey density was 0.8 larvae $\mathrm{l}^{-1}$, based upon larval densities from Zimmerman (1972) and Miller (1995). Unnaturally high prey densities were 100 larvae $\mathrm{l}^{-1}$. Corrals in treatments with $53-\mu \mathrm{m}$ filtered seawater were deployed by lowering them into the water cod-end first. These corrals filled with seawater that was filtered as it passed through the codend mesh. Selected predators were added to all treatments and replicates. Added predators were: 2 Proboscidactyla flavicirrata (hydromedusa), 2 Aurelia sp. ephyrae (scyphomedusa), 1 Muggiaea atlantica (siphonophore), 3 brachyuran zoeae (unidentified decapod), 1 anomuran zoea (unidentified decapod), and 6 trochophores of Arctonöe vittata (polychaete). Each treatment was replicated 3 times. All replicates could not be run simultaneously, so 1 complete set of the 4 treatments was run daily for 3 consecutive days. Predation on marked larvae was scored based on predator gut contents, because high prey densities rendered retrieval of the entire marked population impractical. Gut passage times for the majority of these diverse predators were undetermined. However, the lack of marked fecal pellets in this study, particularly in the 5 runs where $100 \%$ of larvae were recovered in all replicates (zero variance, see 'Results'), indicates that gut passage times are irrelevant. Loss of predation counts due to fecal passage was considered negligible in the light of retrieval efficiency. Observed gut contents thus reflect a relatively accurate record of predation rates. 
Other aspects of deployment, collection and sorting of this experiment were identical to the methods described for the observation runs.

In the second manipulative experiment, designed to examine only the effects of background plankton, nearnatural marked prey densities were held constant, but the presence of background plankton was manipulated. The treatments were: (1) filtered seawater; (2) background plankton present (unfiltered seawater). Marked larvae were added to corrals at densities of 1 larva $\mathrm{l}^{-1}$. As with the experiment manipulating both prey density and background, corrals in the treatment with $53-\mu \mathrm{m}$-filtered seawater were deployed by submerging them cod-end first. Selected predators added to each corral were: 2 Proboscidactyla flavicirrata, 2 Aurelia sp. ephyrae, 1 small stickleback Gasterosteus aculeatus $(\sim 2 \mathrm{~cm}$ in length), 2 brachyuran zoeae, 1 anomuran zoea, and 2 trochophores of Arctonöe vittata. Each treatment consisted of 3 replicates and the entire experiment was concurrent. Other aspects of deployment, collection, and sorting were identical to the methods described for the observation runs.

Encounter estimates. Due to overall low observations of predation in this study (see 'Results'), we attempted to determine if low encounters could be responsible for the lack of predation. To this end, we used Gerritsen \& Strickler's (1977) formula to estimate the total number of encounters between marked larvae and other potential predators in a corral.

$$
Z_{\mathrm{p}}=\frac{\pi R^{2} N_{\mathrm{h}}}{3}\left(\frac{u^{2}+3 v^{2}}{v}\right) \text { for } v>u
$$

This encounter model, tailored for cases where predator speed exceeds that of the prey and prey swim randomly, uses predator encounter radius $R$, prey density $N_{\mathrm{h}}$, and predator and prey swimming speeds, $v$ and $u$ respectively, to determine the number of encounters $\left(Z_{\mathrm{p}}\right)$ of a single predator with its prey. All animals larger than the marked larvae were assumed to be potential predators. Table 2 gives encounter radii and swimming speeds for prey and potential predators. In the absence of estimates of detection radius from the literature, we assumed that predator encounter radius equaled predator body radius. Predator swimming speeds were taken from the literature or, when 'pers. obs.' is indicated, were clocked in the laboratory. Using a ruler or an optical micrometer and stereoscope, whichever was appropriate for a particular predator's size and swimming speed, predators were observed swimming in bowls or Sedgewick-rafter counting cells. We acknowledge the unexplored possibility of laboratory artifacts influencing swimming speeds, but animals did have opportunities to swim freely in their containers, which is when they were clocked. When swimming pattern was complicated by spiraling, we measured an integrated, 2-dimensional swimming speed, this being most appropriate for estimates of encounters using Gerritsen \& Strickler's (1977) model. For hydromedusae that generally forage by sinking quietly through the water column, 'swimming speed' is actually their sinking speed while their tentacles are extended for prey capture. Unreplicated swimming times and distances were recorded for different predator types. To contrast the observed low predation, the estimates given (Table 2) are based upon the highest and lowest numbers of a particular predator counted in a corral replicate, yielding extreme estimates of encounters as a function of species density. Predator encounter radius, however, is very conservative. For predators whose encounter radius exceeds that of their body, actual encounters should be greater than that estimated.

In the 5 runs where predation was observed on marked bivalve veligers (Runs 3, 4, 6, 8 and 10: see Table 3 ) we calculated daily mortality rates, $M$ (see Table 3), as follows (Rumrill 1990):

$$
M=\ln \left(N_{0} / N_{t}\right) /-t
$$

where $N_{0}$ is the initial prey abundance and $N_{t}$ is the final prey abundance after time $t$. Daily mortality rates were used to estimate life-time mortality for larvae, assuming $M$ remains constant for the planktonic life of the larvae (see Table 3).

Because little is known about natural predators on meroplanktonic larvae, predators included may or may not prey on these larval types. Some predators, however, were examined in the laboratory and confirmed to consume larvae under certain conditions. Unfortunately, not enough information is available to confidently exclude the other, more questionable predators. A significant portion of estimated encounters were with calanoid copepods, which were not investigated under laboratory conditions. The calanoids present in experiments represented many species which have not been identified and a range of sizes ( 0.5 to $2.5 \mathrm{~mm})$. Calanoid copepods may be carnivores (Goswami 1977, Lonsdale et al. 1979, Duong 1985, Greene 1988, Greene \& Landry 1988, Tiselius 1988, Metz \& Schnack-Schiel 1995, Vega 1997, Vanderploeg et al. 1998), omnivores (e.g. Graeve et al. 1994, Ward et al. 1996, Cripps \& Hill 1998), or small-particle grazers. We have included copepods of unknown diet to avoid excluding potentially important predators.

\section{RESULTS}

\section{In situ observations}

Marked larvae fluoresced brightly when excited by UV light and viewed through an FITC filter. Glowing 
Table 2. Potential predators, vital parameters, and resulting predator-prey encounter estimates for marked larvae in $24 \mathrm{~h}$ observation runs. Encounter estimates predicted by Gerritsen \& Strickler's (1977) encounter model. Predator encounter radii $(R)$ and predator swimming speeds $(v)$ were used in calculating low and high encounter estimates based on lowest and highest average run abundances ( $\mathrm{n}=4$ corrals), where $R$ is a minimum estimate of encounter radius:predator body radius. Prey swimming speeds (u) used for estimating encounters were $0.015 \mathrm{~cm} \mathrm{~s}^{-1}$ for echinoid plutei (K. B. Johnson pers. obs.), $0.03 \mathrm{~cm} \mathrm{~s}^{-1}$ for bivalve veligers (Hidu \& Haskin 1978), and $0.09 \mathrm{~cm} \mathrm{~s}^{-1}$ for gastropod veligers (Konstantinova 1966). Total confirmed encounters (i.e. mean observed predation) are displayed at bottom of table for comparison with encounter estimate totals. Predators highlighted in bold are confirmed to ingest larvae under unnatural laboratory conditions, while other predators are untested

\begin{tabular}{|c|c|c|c|c|c|c|c|c|c|}
\hline \multirow[t]{3}{*}{ Predator } & \multirow[t]{3}{*}{$\begin{array}{c}R \\
(\mathrm{~cm})\end{array}$} & \multirow[t]{3}{*}{$\begin{array}{c}V \\
\left(\mathrm{~cm} \mathrm{~s}^{-1}\right)\end{array}$} & \multirow[t]{3}{*}{ Source for $v$} & \multicolumn{6}{|c|}{$\begin{array}{l}\text { Estimates of encounters with predators } \\
\left(\text { mean no. corral }{ }^{-1}\right)\end{array}$} \\
\hline & & & & \multicolumn{2}{|c|}{$\begin{array}{l}\text { Echinoid } \\
\text { plutei }\end{array}$} & \multicolumn{2}{|c|}{$\begin{array}{l}\text { Bivalve } \\
\text { veligers }\end{array}$} & \multicolumn{2}{|c|}{$\begin{array}{c}\text { Gastropod } \\
\text { veligers }\end{array}$} \\
\hline & & & & Low & High & Low & High & Low & High \\
\hline Calanoid copepods & 0.02 & 1.2 & J. R. Strickler (pers. comm.) & 60 & 269 & 17 & 269 & 39 & 43 \\
\hline Harpacticoid copepods & 0.02 & 0.6 & K. B. Johnson (pers. obs.) & 0 & 2 & 0 & 2 & 1 & 2 \\
\hline Gammarid amphipods & 0.04 & 1.0 & K. B. Johnson (pers. obs.) & 0 & 0 & 0 & 0 & 0 & 0 \\
\hline Hyperiid amphipods & 0.04 & 1.5 & K. B. Johnson (pers. obs.) & 0 & 4 & 0 & 1 & 0 & 2 \\
\hline Anomuran zoeae & 0.03 & 0.9 & $\begin{array}{l}\text { Knudsen (1960), Latz \& Forward (1977), } \\
\text { Cronin \& Forward (1980), Forward \& } \\
\text { Cronin (1980), Sulkin }(1973,1975)\end{array}$ & 0 & 0 & 0 & 0 & 0 & 0 \\
\hline Brachyuran zoea & 0.03 & 0.9 & $\begin{array}{l}\text { Knudsen (1960), Latz \& Forward (1977), } \\
\text { Cronin \& Forward (1980), Forward \& } \\
\text { Cronin (1980), Sulkin }(1973,1975)\end{array}$ & 0 & 1 & 0 & 1 & 0 & 0 \\
\hline Cumacea & 0.06 & 2.0 & K. B. Johnson (pers. obs.) & 0 & 0 & 0 & 10 & 0 & 0 \\
\hline Euphausid calyptopis zoea & 0.04 & 1.5 & K. B. Johnson (pers. obs.) & 0 & 1 & 0 & 0 & 0 & 0 \\
\hline Obelia sp. & 0.02 & 0.5 & Sinking rate, K. B. Johnson (pers. obs.) & 0 & 1 & 0 & 1 & 0 & 1 \\
\hline Phialidium sp. & 0.3 & 0.5 & Sinking rate, K. B. Johnson (pers. obs.) & 0 & 30 & 0 & 30 & 0 & 5 \\
\hline Aglantha digitale & 0.2 & 2.0 & Sinking rate, K. B. Johnson (pers. obs.) & 0 & 20 & 0 & 20 & 0 & 0 \\
\hline Leptomedusa & 0.03 & 0.5 & Sinking rate, K. B. Johnson (pers. obs.) & 0 & 12 & 0 & 3 & 0 & 1 \\
\hline Rathkea octopunctata & 0.03 & 0.5 & Sinking rate, K. B. Johnson (pers. obs.) & 0 & 0 & 0 & 0 & 0 & 0 \\
\hline Proboscidactyla flavicirrata & 0.3 & 0.5 & Sinking rate, K. B. Johnson (pers. obs.) & 0 & 24 & 0 & 24 & 10 & 10 \\
\hline Sarsia sp. & 0.1 & 0.5 & Sinking rate, K. B. Johnson (pers. obs.) & 0 & 0 & 0 & 1 & 0 & 1 \\
\hline Aurelia sp. ephyra & 0.06 & 0.2 & K. B. Johnson (pers. obs.) & 0 & 1 & 0 & 1 & 0 & 0 \\
\hline Pleurobrachia bachei & 0.4 & 0.5 & Sinking rate, K. B. Johnson (pers. obs.) & 0 & 22 & 0 & 22 & 0 & 0 \\
\hline Cydippid larvae & 0.01 & 0.6 & K. B. Johnson (pers. obs.) & 0 & 1 & 0 & 1 & 0 & 0 \\
\hline Autolytus sp. & 0.02 & 1.9 & K. B. Johnson (pers. obs.) & 0 & 1 & 0 & 1 & 0 & 1 \\
\hline $\begin{array}{l}\text { Spionid metatrocho- } \\
\text { phores }\end{array}$ & 0.02 & 0.1 & Konstantinova (1969) & 0 & 2 & 0 & 2 & 0 & 0 \\
\hline $\begin{array}{l}\text { Miscellaneous metatrocho- } \\
\text { phores }\end{array}$ & 0.04 & 0.1 & Konstantinova (1969) & 0 & 31 & 0 & 32 & 4 & 6 \\
\hline Nectochaetae & 0.03 & 0.1 & Konstantinova (1969) & 0 & 0 & 0 & 0 & 0 & 0 \\
\hline Magelona sp. & 0.02 & 0.3 & K. B. Johnson (pers. obs.) & 0 & 1 & 0 & 1 & 0 & 0 \\
\hline Miscellaneous trochophores & 0.04 & 0.2 & Konstantinova (1969) & 0 & 3 & 0 & 2 & 0 & 1 \\
\hline $\begin{array}{l}\text { Arctonöe vitatta trocho- } \\
\text { phores }\end{array}$ & 0.02 & 0.3 & B. Pernet (pers. comm.) & 0 & 0 & 0 & 0 & 0 & 0 \\
\hline Chaetognaths & 0.1 & 0.3 & K. B. Johnson (pers. obs.) & 0 & 1 & 0 & 1 & 0 & 0 \\
\hline Larval fishes & 0.2 & 1.2 & K. B. Johnson (pers. obs.) & 0 & 5 & 0 & 5 & 0 & 0 \\
\hline Noctiluca scintillans & 0.05 & 0.028 & Kiørboe \& Titelman (1998) & 0 & 5 & 0 & 6 & 0 & 0 \\
\hline \multicolumn{4}{|c|}{ Total estimated no. of encounters } & 60 & 437 & 17 & 436 & 54 & 73 \\
\hline \multicolumn{4}{|l|}{ Total observed predation } & 0 & 0 & 0 & 7 & 0 & 0 \\
\hline
\end{tabular}

skeletons were visible against the background plankton collected from corrals (Fig. 2A,B) and inside predators (Fig. 2C-F). We recovered nearly all marked larvae, allowing reliable estimates of predation in corrals. Mean recovery for runs ranged from 96.5 to $100 \%$. Average mean recovery for this study was $99.0 \%$ $( \pm 0.25 \% \mathrm{SE}$ ). In 5 runs, 1 for plutei (Run 1$)$ and 4 for bivalve veligers (Runs 1, 4, 5, and 9), all larvae were recovered in all replicates (mean recovery $=100 \% \pm 0$ $\mathrm{SE}$ ). All recovered larvae were either intact and apparently alive at fixation or, in a minority of cases, in predator guts. The fate of unrecovered larvae cannot be directly determined but, since marked skeletons were visible under all circumstances, it is assumed that 


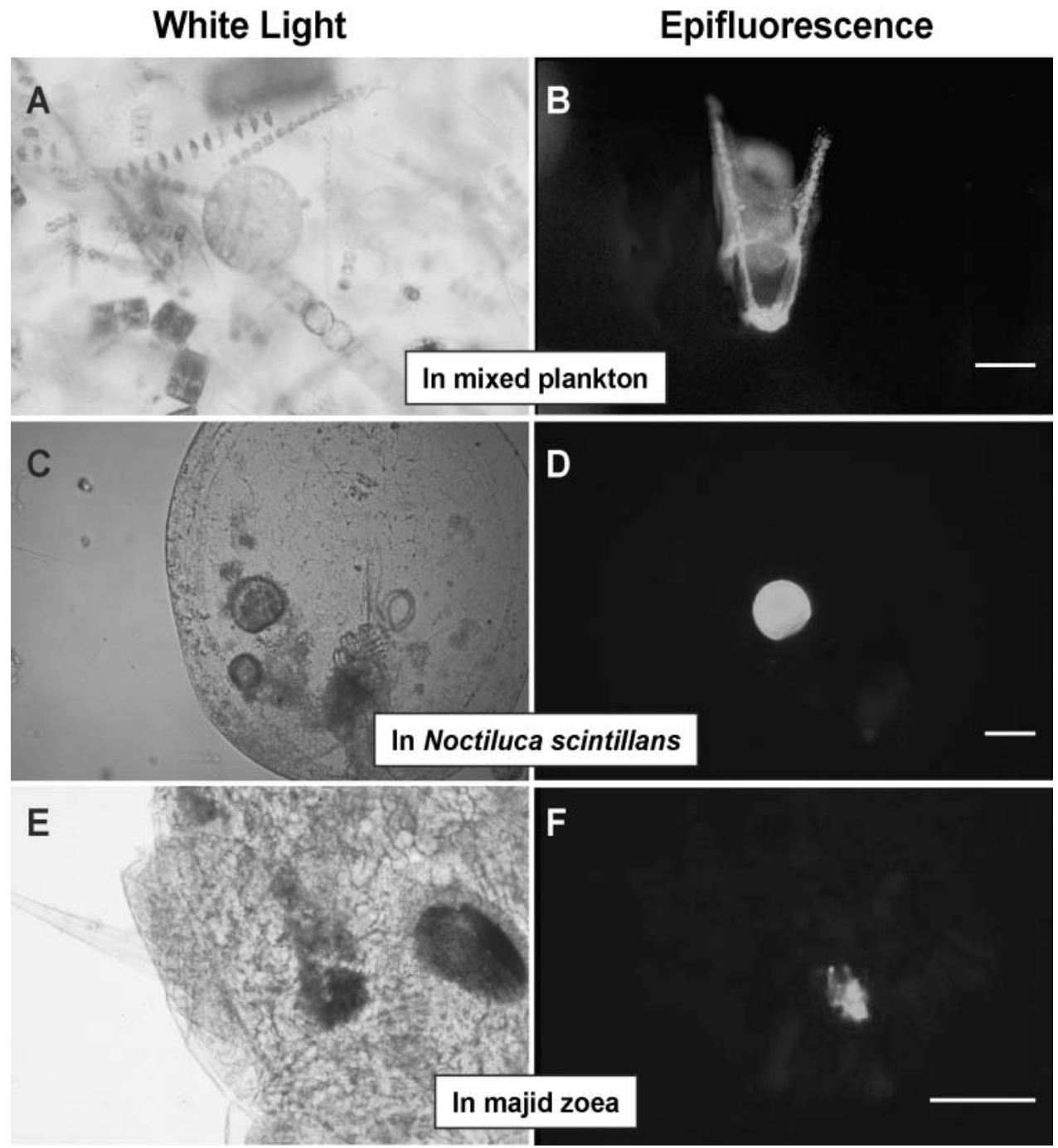

Fig. 2. Epifluorescence microscopy aids in locating recaptured larvae. (A) Field of view through compound microscope $(10 \times$ objective magnification) illuminated with white light. Myriad background plankton (phytoplankton and zooplankton) obscure location of larvae; in this case, the larva is undetectable in another focal plane. (B) Same view as in $(\mathrm{A})$, observed under epifluorescence (fluorescein isothiocyanate filter) reveals presence of a Calcein-marked pluteus; focus was adjusted to appropriate plane after the presence of the larva was revealed by fluorescence. (C) Heterotrophic dinoflagellate Noctiluca scintillans observed under white light. (D) Same view as in (C), observed with epifluorescence to reveal that phagocytized prey is a marked veliger. (E) Majid zoea flattened with slide coverslip and observed under white light. (F) Same view as (E), observed under epifluorescence; fluorescent bolus of a crushed marked pluteus skeleton is visible in the zoea's intestine.

All scale bars $=100 \mu \mathrm{m}$

Table 3. Predation on marked bivalve veliger larvae during in situ observations. Mortality $(M)$ represents mean loss to corral populations in $24 \mathrm{~h}(\mathrm{n}=4) . M$ was then used to estimate \% larvae expected to be eaten after $28 \mathrm{~d}$. In 3 cases $(4,6 \mathrm{~b}$, and 8 ) indicated predators consumed only a single marked bivalve veliger. Note that veligers were not used as prey in Run 2; Run 6 was the only run in which more than 1 predator species was observed

\begin{tabular}{|lrcl}
\hline Run & $\begin{array}{c}M \\
\left(\mathrm{~d}^{-1}\right)\end{array}$ & $\begin{array}{c}\text { Estimated loss } \\
\text { after 28 d (\%) }\end{array}$ & $\begin{array}{l}\text { Predator (total no. of veligers } \\
\text { consumed in all 4 replicates) }\end{array}$ \\
\hline 1 & 0.000 & 0 & None (0) \\
3 & -0.070 & 87 & Noctiluca scintillans (28) \\
4 & -0.005 & 13 & Proboscidactyla flavicirrata (1) \\
5 & 0.000 & 0 & None (0) \\
$6 \mathrm{a}$ & -0.035 & 63 & Noctiluca scintillans (14) \\
$6 \mathrm{~b}$ & -0.003 & 7 & Spionid metatrochophore (1) \\
7 & 0.000 & 0 & None (0) \\
8 & -0.003 & 7 & Gasterosteus aculeatus (1) \\
9 & 0.000 & 0 & None (0) \\
10 & -0.004 & 11 & Proboscidactyla flavicirrata (2) \\
\hline
\end{tabular}

unrecovered larvae were no more likely to have been victims of predation than recovered larvae from the same corrals. Neither marked fecal pellets nor digested portions of skeletons were observed in corrals.

Observations of predation on marked bivalve veligers are summarized in Table 3. In 4 of 9 runs using marked bivalve larvae as prey, no predation on bivalves was observed; in spite of the fact that $100 \%$ of the larvae were often recovered. In 9 runs using marked pluteus larvae, only a single larva was eaten (by Proboscidactyla flavicirrata in Run 10). No predation was observed on marked gastropod veligers during the 2 runs in which they were included.

Predators confirmed to prey on marked bivalves (Table 3 ) often fed at very low rates during our observation runs. In Runs 4 and 8, only a single marked veliger was consumed (i.e. 
only 1 of the 4 replicates showed any predation). Likewise in Run 6, in addition to predation by Noctiluca scintillans, a single spionid metatrochophore larva consumed 1 marked veliger. In Run 10, 2 marked bivalve veligers were observed in the gut of the hydromedusa Proboscidactyla flavicirrata. With the exception of predation by N. scintillans in Runs 3 and 6 , observed predation never occurred consistently in all replicates.

These observational runs included a variety of potential predators and abundant background plankton captured during corral deployment. The abundant organisms are listed in Table 4. Corrals captured dozens of potential predator types representing 7 phyla and a wide variety of planktonic feeding strategies (Greene 1985). Many of the potential predator types were confirmed to ingest larvae under unnatural laboratory conditions. When a type of organism was never represented in numbers $>2$ ind. corral $^{-1}$, or when a type was represented in only 1 run with numbers not exceeding 25 ind. corral $^{-1}$, they were excluded from Table 4 and are listed in the legend as additional background only. Background plankton, including a diversity of phytoplankton, protists, particulate matter, and presumably bacteria, were always present.

Table 4. Background plankton present during in situ observations, showing potential predators randomly captured when corrals were deployed (mean no. corral $^{-1}, \mathrm{n}=4$ ). Run nos. are given under months; $(\mathrm{N})$ ) runs loaded at night. Corral volume was 123 l. The following organisms were occasionally present as background, but were excluded from this table because their abundance never exceeded 2 ind. corral $^{-1}$ : euphausid calyptopis zoeae, salt water mites, larval fishes, the ctenophore Pleurobrachia bachei, and the hydromedusae Aglantha digitale and Rathkea octopunctata. The following were excluded from the table because they were present in only 1 run and their abundance did not exceed 25 ind. corral $^{-1}$ : gammarid amphipods, brachyuran megalopae, cumaceans, nectochaetes (Polychaeta), mitraria (Polychaeta), pilidia (Nemertea), doliolaria (Holothuroidea), ophioplutei (Ophiuroidea), and newly metamorphosed juvenile urchins (Echinoidea)

\begin{tabular}{|c|c|c|c|c|c|c|c|c|c|c|}
\hline \multirow[t]{3}{*}{ Plankton type } & \multicolumn{4}{|c|}{$\longrightarrow$ Coos Bay } & \multicolumn{6}{|c|}{ —Friday Harbor } \\
\hline & \multicolumn{2}{|c|}{ — April — } & \multicolumn{2}{|c|}{ 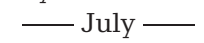 } & & & & & & \\
\hline & 1 & 2 & 3 & 4 & $5(\mathrm{~N})$ & $6(\mathrm{~N})$ & $7(\mathrm{~N})$ & 8 & 9 & 10 \\
\hline Protoperidinium sp. & 0 & 0 & 365 & 0 & 0 & 0 & 32423 & 7740 & 3150 & 25364 \\
\hline Noctiluca scintillans & 1531 & 413 & 540 & 489 & 404 & 375 & 0 & 0 & 0 & 0 \\
\hline Coscinodiscus sp. & 0 & 0 & 0 & 0 & 0 & 0 & 12938 & 6420 & 9923 & 10025 \\
\hline Tintinnids & 193 & 376 & 164 & 0 & 0 & 0 & 0 & 0 & 14 & 0 \\
\hline Copepods (calanoid) & 653 & 565 & 922 & 737 & 817 & 1838 & 2543 & 840 & 1215 & 1520 \\
\hline Copepods (harpacticoid) & 0 & 101 & 101 & 225 & 72 & 55 & 113 & 16 & 26 & 21 \\
\hline Nauplii (copepod) & 1806 & 545 & 1849 & 1787 & 1812 & 23464 & 9428 & 8640 & 4275 & 3755 \\
\hline Nauplii (barnacle) & 1439 & 440 & 1068 & 334 & 268 & 949 & 270 & 43 & 42 & 35 \\
\hline Cyprids (barnacle) & 0 & 13 & 0 & 0 & 0 & 27 & 0 & 8 & 4 & 12 \\
\hline Amphipods (hyperiid) & 0 & 0 & 0 & 1 & 28 & 2 & 9 & 11 & 3 & 5 \\
\hline Cryptoniscus (isopod) & 0 & 0 & 0 & 0 & 0 & 0 & 0 & 5 & 1 & 0 \\
\hline Zoeae (anomuran) & 0 & 0 & 0 & 0 & 2 & 0 & 2 & 0 & 4 & 1 \\
\hline Zoeae (brachyuran) & 0 & 0 & 0 & 0 & 0 & 2 & 1 & 0 & 5 & 3 \\
\hline Cladocera & 0 & 0 & 11 & 8 & 1 & 0 & 0 & 0 & 0 & 0 \\
\hline Ostracoda & 0 & 0 & 0 & 0 & 0 & 0 & 1 & 3 & 0 & 0 \\
\hline Obelia sp. & 21 & 0 & 22 & 35 & 3 & 0 & 2 & 0 & 3 & 1 \\
\hline Phialidium sp. & 0 & 1 & 0 & 1 & 0 & 1 & 3 & 0 & 1 & 0 \\
\hline Leptomedusa & 0 & 42 & 0 & 8 & 1 & 0 & 2 & 0 & 19 & 0 \\
\hline Cydippid larvae & 45 & 0 & 0 & 0 & 0 & 0 & 0 & 0 & 0 & 0 \\
\hline Autolytus sp. & 0 & 0 & 0 & 0 & 8 & 4 & 5 & 3 & 4 & 1 \\
\hline Spionids & 0 & 0 & 0 & 0 & 0 & 0 & 228 & 35 & 26 & 11 \\
\hline Metatrochophores & 792 & 259 & 415 & 240 & 167 & 662 & 70 & 13 & 7 & 3 \\
\hline Magelona sp. & 42 & 50 & 16 & 0 & 0 & 0 & 0 & 0 & 0 & 0 \\
\hline Trochophores & 34 & 42 & 8 & 12 & 24 & 27 & 0 & 0 & 0 & 0 \\
\hline Cyphonautes & 0 & 3 & 6 & 22 & 15 & 17 & 5 & 8 & 4 & 0 \\
\hline Echinoplutei & 241 & 48 & 5 & 0 & 23 & 0 & 0 & 0 & 0 & 0 \\
\hline Veligers (bivalves) & 404 & 83 & 112 & 0 & 0 & 192 & 96 & 115 & 126 & 48 \\
\hline Veligers (gastropods) & 13 & 26 & 9 & 50 & 22 & 30 & 9 & 19 & 8 & 15 \\
\hline Egg cases & 0 & 0 & 0 & 0 & 4 & 3 & 0 & 0 & 0 & 0 \\
\hline Embryos & 216 & 148 & 53 & 0 & 0 & 95 & 0 & 0 & 0 & 0 \\
\hline Eggs & 92 & 331 & 0 & 0 & 48 & 4 & 0 & 0 & 0 & 0 \\
\hline Chaetognaths & 20 & 26 & 22 & 9 & 67 & 71 & 62 & 32 & 15 & 13 \\
\hline Larvaceans & 234 & 9 & 89 & 114 & 102 & 55 & 16 & 8 & 31 & 20 \\
\hline
\end{tabular}




\section{Predation rates on wild larvae}

Though we identified all predators of marked larvae by epifluorescence microscopy, it is also possible to measure predation rates on wild larvae from the captured water column. The gut contents of selected predators (all cnidarians, all ctenophores, chaetognaths, fishes, and Arctonöe vittata trochophores) were examined to determine predation on wild larvae. These predators were selected because they are considered by many to be important predators and their typical prey sizes encompass the sizes of larvae in corrals (Nelson 1925, Hirota 1974, Bailey et al. 1975, Hobson \& Chess 1976, Reeve 1980, Purcell \& Mills 1988, Rumrill 1990, Purcell et al. 1991, 1994, AlvarezCadena 1993, Chandy \& Greene 1995, Morgan 1995, Phillips \& Pernet 1996, Johnson \& Brink 1998). The most common prey items observed were adult copepods, nauplii (Table 5), and phytoplankton. Some of these predators also consumed unmarked veligers that were part of the natural plankton assemblage (Table 5).

\section{Density and background experiments}

In the experiment that manipulated prey density and background plankton, results were the same for both marked plutei and marked bivalve veligers (Fig. 3). Most predators consumed larvae at high densities when larvae were presented in filtered seawater. Observed predation, however, almost completely disappeared at lower, near-natural prey densities. At the unnaturally high prey densities, the inclusion of natural background plankton reduced predation on marked

Table 5. Number (mean \pm SE) of wild invertebrate larvae per gut observed in in situ corrals. Numbers calculated from data pooled across all runs and replicates. All prey listed were part of the natural assemblage

\begin{tabular}{|c|c|c|c|}
\hline \multirow[t]{2}{*}{ Predator } & \multicolumn{3}{|c|}{ Unmarked prey type } \\
\hline & $\begin{array}{c}\text { Nauplii } \\
\text { (copepod and } \\
\text { barnacle) }\end{array}$ & $\begin{array}{c}\text { Veligers } \\
\text { (bivalve and } \\
\text { gastropod) }\end{array}$ & $\begin{array}{c}\text { Meta- } \\
\text { trochophores } \\
\text { (polychaete) }\end{array}$ \\
\hline Sagitta sp. (chaetognath, $\mathrm{n}=20$ ) & $1.80 \pm 0.30$ & None & None \\
\hline $\begin{array}{l}\text { Gasterosteus aculeatus } \\
\text { (stickleback, } \mathrm{n}=6 \text { ) }\end{array}$ & $81.5 \pm 9.22$ & None & None \\
\hline $\begin{array}{l}\text { Pleurobrachia bachei } \\
\text { (comb jelly, } \mathrm{n}=20 \text { ) }\end{array}$ & $3.10 \pm 0.72$ & $0.05 \pm 0.05$ & $0.05 \pm 0.05$ \\
\hline $\begin{array}{l}\text { Proboscidactyla flavicirrata } \\
\text { (hydromedusa, } \mathrm{n}=41 \text { ) }\end{array}$ & $1.49 \pm 0.39$ & $0.73 \pm 0.16$ & $0.29 \pm 0.10$ \\
\hline Sarsia sp. (hydromedusa, $\mathrm{n}=4$ ) & $3.00 \pm 0.41$ & $0.25 \pm 0.25$ & $0.25 \pm 0.25$ \\
\hline $\begin{array}{l}\text { Phialidium sp. } \\
\text { (hydromedusa, } \mathrm{n}=27 \text { ) }\end{array}$ & $1.63 \pm 0.32$ & $0.11 \pm 0.06$ & $0.07 \pm 0.05$ \\
\hline
\end{tabular}

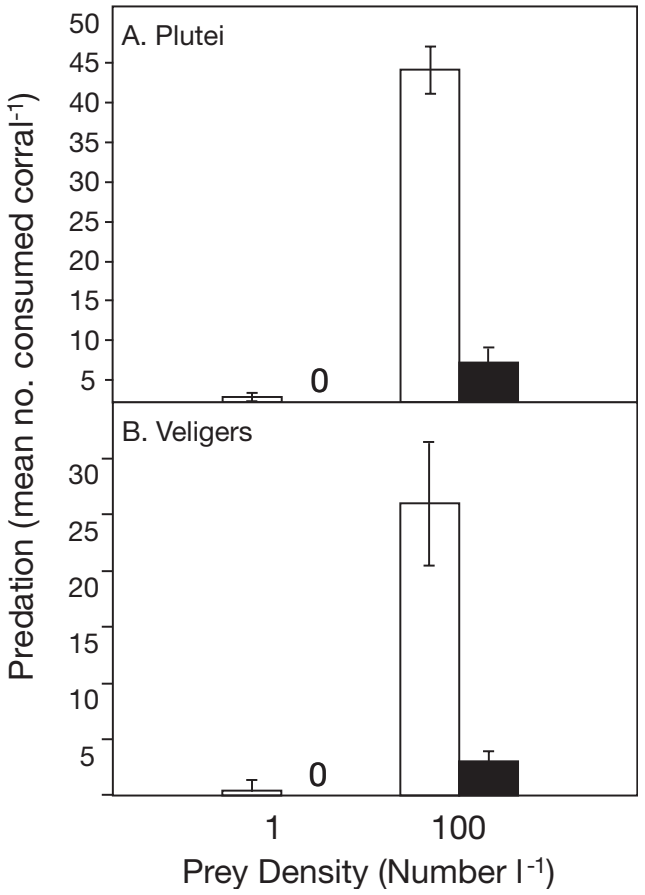

Fig. 3. Effects of prey density and background plankton on larval predation in density and background experiment for (A) marked plutei and (B) marked veligers. Data combined for all predators included in the experiment (listed in 'Materials and methods'). Open bars: $53-\mu m$-filtered seawater treatments; black bars: treatments with background plankton present; 0 : zero mean and variance in mortality; error bars $=95 \% \mathrm{CI}$

plutei and bivalve veligers by an average of 37 and $23 \%$, respectively (Fig. 3). Predators responsible for the predation observed in this experiment were hydromedusae, decapod zoeae, scyphozoan ephyrae, and 1 polychaete trochophore (Table 6). When prey were presented at near-natural prey densities and in the presence of natural background plankton, no predation on larvae was observed by any predators (Fig. 3; no predation indicated by ' 0 ').

Results of the background experiment, in which only a natural prey density was used, were consistent with the findings of the prey density experiment. Predation was almost entirely absent, with the only observed predation being on a single marked bivalve veliger in filtered seawater. As with the prey-density experiment, when prey were presented under the most natural conditions (i.e. at near-natural prey densities and in the presence of natural background plankton) no predation was observed on larvae. 
Table 6. Prey-density and background experiment: predators on marked plutei (P) and veligers (V) as a function of treatment, showing cumulative total numbers (not means) consumed in all treatments (total prey consumed in all 3 replicates given in parentheses). Experiments were conducted at near-natural and unnaturally high prey densities in either 53- $\mu \mathrm{m}$-filtered seawater (FSW) or with background plankton (BG) present. np: no predation

\begin{tabular}{|c|c|c|c|c|}
\hline \multirow[t]{2}{*}{ Predator } & \multicolumn{2}{|c|}{$\begin{array}{l}\text { Near-natural prey density } \\
\left(1 \text { larvae } l^{-1}\right)\end{array}$} & \multicolumn{2}{|c|}{$\begin{array}{l}\text { Unnaturally high prey density } \\
\qquad\left(100 \text { larvae } l^{-1}\right)\end{array}$} \\
\hline & FSW & BG & FSW & BG \\
\hline Proboscidactyla flavicirrata & $\mathrm{P}(0) ; \mathrm{V}(1)$ & $\mathrm{np}$ & $\mathrm{P}(83) ; \mathrm{V}(57)$ & $\mathrm{P}(13)_{i} \mathrm{~V}(4)$ \\
\hline Phialidium sp. & $\mathrm{np}$ & $\mathrm{np}$ & $\mathrm{np}$ & $\mathrm{P}(0) ; \mathrm{V}(4)$ \\
\hline Aurelia sp. ephyrae & np & $\mathrm{np}$ & $\mathrm{P}(4)_{i} \mathrm{~V}(1)$ & $\mathrm{P}(1) ; \mathrm{V}(0)$ \\
\hline Brachyuran zoeae & $\mathrm{P}(1) ; \mathrm{V}(0)$ & np & $\mathrm{P}(17) ; \mathrm{V}(0)$ & $\mathrm{P}(1) ; \mathrm{V}(0)$ \\
\hline Anomuran zoeae & $\mathrm{np}$ & $\mathrm{np}$ & $\mathrm{P}(2) ; \mathrm{V}(0)$ & $\mathrm{P}(1) ; \mathrm{V}(0)$ \\
\hline Arctonöe vittata & $\mathrm{np}$ & $\mathrm{np}$ & $\mathrm{P}(0) ; \mathrm{V}(16)$ & np \\
\hline
\end{tabular}

\section{DISCUSSION}

For the assemblages examined, predation was always low or absent for marked plutei and gastropod veligers. Mortality of marked bivalve veligers due to predators reveals a more complex story, although predation was still often completely absent (4 of 10 replicated runs). Only 1 observed predator on bivalve veligers, the dinoflagellate Noctiluca scintillans, appeared to be capable of dramatically reducing the population. A few other predators on veligers were identified, but the potential impact of these predators on our larval populations was trivial (Table 3). Assuming consistent ingestion rates, predation on wild larvae in the same assemblages revealed that barnacle and copepod nauplii were consumed far more often than mollusc, polychaete, and echinoid larvae. Low predation on ciliated larvae, if low in nature, would indicate an increased role for alternative mortality sources and could influence theory addressing the life-history evolution of marine invertebrates with complex life cycles.

Low or absent predation seems to contradict the predictions and evidence of other studies (reviewed in Rumrill 1990). Laboratory feeding experiments have identified planktonic predators feeding at high rates on larvae such as plutei and veligers (Pennington \& Chia 1984, Rumrill et al. 1985, Pennington et al. 1986, Toonen \& Chia 1993). However, laboratory experiments present prey in filtered seawater and at densities that are probably unnaturally high. It has been shown that laboratory predators may eat prey that would otherwise be unconsumed under more natural conditions (Johnson \& Shanks 1997). There are many studies that have examined the gut contents of filterfeeding fishes and gelatinous zooplankton and noted the presence of various larval forms (e.g. Emery 1973, Bailey et al. 1975, Purcell 1981). Often primary prey are copepods or other holoplankters (Emery 1973,
Bailey et al. 1975, Hobson \& Chess 1978, Purcell 1981, Turner 1984); occasional observations of veligers or other larvae in gut samples tell little about the predator's impact on the larval population because initial and final population numbers are unknown. Studies monitoring larval cohorts in the field are able to document declining numbers in the plankton, but do not identify the source of loss (e.g. Quayle 1964, Jørgensen 1981). Although a natural predator may be identified based upon gut-content analysis in studies such as these, the overall significance of that predator for the larval population cannot be determined because the proportion of the original prey population consumed by the predator often remains unknown. The lack of published mortality rates determined by direct observation has prompted statements such as 'there are no reliable estimates of larval mortalities in plankton' (Sastry 1985) and 'many unresolved questions remain about exactly how much mortality occurs in the plankton and the source of that mortality' (Pechenik 1999).

\section{Mechanisms of low predation}

Corral observations were targeted at determining the general risk to larval populations in diverse nearnatural assemblages. Low predation observed in corrals is potentially due to one or more of the following reasons: predators are inefficient at capturing prey, larvae have an effective escape response, predators present do not eat larvae, or encounters between predators and prey are scarce. Capture efficiency is undetermined for the many predator-prey combinations brought together in corral assemblages, but efficiency would decrease when larvae have an effective escape response. Plutei can use cilia to abruptly reverse swimming direction, and this ability appears to make them less vulnerable to predation (Rumrill et al. 1985); veligers withdraw their velum and sink quickly through the water column when disturbed (LaBarbera 1974), a behavior that may be useful in avoiding a variety of predator types. Results of our density and background experiments indicate that many of the predators examined will feed on plutei and/or veligers when prey are presented at high densities in filtered seawater. The disappearance of predation at near-natural 
densities suggests that predation is rare, perhaps due to low encounter rates. Interference by background plankton also plays a role in reducing predation. In the corrals, many captured and seeded predators preyed on veligers and plutei when they were presented at unnaturally high densities or in the absence of natural background plankton. Johnson \& Shanks (1997) and Johnson \& Brink (1998) made similar observations in laboratory studies of planktonic predation on echinoid embryos, plutei, barnacle nauplii, and bivalve veligers. Hansen et al. (1991) found that non-grazeable background particles reduced prey capture by a tintinnid, a rotifer, a gastropod veliger, and young copepods. Cowan \& Houde (1993) observed reduction of feeding on fish eggs and larvae by the bay anchovy Anchoa mitchilli when alternative zooplankton prey were present. We have previously proposed that background plankton can reduce encounters between predators and larvae, obscure larvae from detection or capture, or serve as substitute food, occupying or satiating the predator (Johnson \& Shanks 1997). We suggest that laboratory and field studies of planktonic predators, as well as planktonic encounter models, might be improved by considering the potential effects of background plankton.

\section{Predation on wild nauplii}

Wild nauplii were consumed far more often than ciliated larvae (see Table 5 for nauplius predator identities). This may simply be due to the fact that their numbers far exceeded those of other larval types in corrals. For example, the corral average of 23464 ( \pm 6098 SD) copepod nauplii in Run 6 (see Table 4) is more than 2 orders of magnitude greater than the marked pluteus and veliger densities (100 ind. corral $^{-1}$ ). This probably reflects a natural disparity; ambient pluteus and veliger densities reported in the literature are rarely as high as nauplius densities, and were always much lower in the corral assemblages. Juvenile sticklebacks (Gasterosteus aculeatus; Run 8) fed almost entirely on nauplii and, based on a comparison of gut vs corral ratios using the $C$-index (Pearre 1982), strongly preferred barnacle nauplii over copepod nauplii ( $\mathrm{p}<$ 0.001, df = 2).

High prey abundance may influence predator behavior and the evolution of foraging, providing additional explanations for the observed low predation on plutei and veligers vs the relatively high predation on nauplii. Predators may evolve effective foraging and capture strategies specifically targeted towards consistently abundant prey (Tinbergen 1960, Gibb 1962). For example, visual and vibration-sensing predators have evolved means of prey detection that rely on the jerky swimming movements of crustacean prey (Horridge \& Boulton 1967, Feigenbaum \& Reeve 1977, Bailey \& Yen 1983, Yen 1987, Yen \& Nicoll 1990, DeMott \& Watson 1991), which are the most consistently abundant metazoan stock in the planktonic environment. Animals hunting in this manner may detect nauplii at relatively great distances and yet ignore nearby ciliated swimmers such as veligers and plutei. As a result of consistent high abundance, more predators and stronger predator-prey relationships may have evolved for nauplii than the ciliated larval types investigated.

\section{Predation on bivalve veligers}

The hydromedusa Proboscidactyla flavicirrata preyed on bivalve veligers in corrals, although its potential impact was low relative to that of Noctiluca scintillans. Other researchers have identified medusae, including P. flavicirrata, as predators on veligers (e.g. Purcell \& Mills 1988, Larson 1991), and Toonen \& Chia (1993) concluded that $P$. flavicirrata specializes in feeding on veligers. In our corrals, mortality of marked bivalve larvae by $P$. flavicirrata was $-0.0025 \mathrm{~d}^{-1}$, which could potentially result in a $7 \%$ reduction of a veliger population over a 28 d planktonic period - a reasonable larval duration for many bivalves.

Proboscidactyla flavicirrata, apparently a natural predator of bivalve veligers, may feed primarily on larger veligers. We observed that $P$. flavicirrata often consumed wild, unmarked bivalve veligers that were larger (approx. 250 to $350 \mu \mathrm{m}$ ) than the marked d-hinge oyster veligers $(90 \mu \mathrm{m})$. In unpublished laboratory feeding experiments in which $P$. flavicirrata was simultaneously presented with both 280 and $90 \mu \mathrm{m}$ veligers, they preferentially fed on the larger larvae. We estimated as many as 30 encounters between $P$. flavicirrata and marked bivalve veligers (see Table 2), although only 3 of these veligers were consumed (1 veliger in Run 4, and 2 veligers in Run 10). These data suggest that $P$. flavicirrata selects the larger veligers from a natural assemblage.

\section{Predation by a heterotrophic dinoflagellate}

In 2 observation runs, 3 and 6, we found substantial predation on marked bivalve veligers by Noctiluca scintillans. Mean mortality of bivalve veligers due to $N$. scintillans was -0.07 and $-0.04 \mathrm{~d}^{-1}$ for Runs 3 and 6 , respectively (Table 3). Assuming consistent rates of predation, these mortality rates extrapolated over a 28 d planktonic period would produce total population losses of 87 and $63 \%$, respectively (Table 3). This predation represented a substantial threat to the veliger 
population, but bivalve predation did not always occur in the presence of $N$. scintillans. The dinoflagellate was present in the first 6 runs (Table 4), but only consumed larvae in Runs 3 and 6 (Table 3). While to our knowledge this is the first study identifying $N$. scintillans as predator on veligers, the dinoflagellate is notorious for consuming metazoan zooplankters, including various crustaceans such as copepods and larvae (Enomoto 1956, Prasad 1958), fish eggs (Hattori 1962), and even chaetognaths (Prasad 1958). It should be noted that studies with other predators have observed that large proportions of oyster veligers (75 to $99 \%$ ) may avoid digestion in the guts of coelenterate predators by tightly closing their valves (Purcell et al. 1991). We did not confirm digestion of veligers by $N$. scintillans and, if digestion resistance is similar to that of oyster veligers in coelenterate guts, observations of predation by the dinoflagellate could overestimate mortality.

\section{Encounter estimates}

The simplest explanation for the general lack of predation in our observations is that, at natural densities, predators and prey did not encounter one another. Mean estimated prey encounters in $24 \mathrm{~h}$ with a single predator type ranged from 0 to 269 . The highest estimate was for encounters with large calanoid copepods (Observation Run 7). Actual observed predation by any predator on bivalves, however, was completely absent in Runs 1, 2, 5, 7, and 9, and nearly absent in Runs 4,8 , and 10. In the run where a single pluteus was eaten (Observation Run 10) the mean estimate for plutei encountering potential predators was 247 . Assuming predators attempt to consume plutei and that encounter estimates are correct, this would indicate very low capture success rates $(<1 \%)$. Similar comparisons for encounter estimates with bivalve veligers indicate that for all predators, excepting Noctiluca scintillans, capture success rates would be low.

\section{Corral conditions}

Predation on invertebrate larvae has never been examined with the conditions and variety of predators used in this study. Valuable conditions included reasonable prey densities, the presence of background plankton, naturally co-occurring species in the assemblage, alternative prey, known initial prey densities, large container volume (relative to laboratory experiments), in situ locale, and precise determination of marked larval fates. This study necessarily also included unnatural conditions that could create bias, including restriction of the plankton assemblage to the upper $1 \mathrm{~m}$ of the water column, the enclosed environment of the corral, assemblage sub-sampling, and short duration. These assemblages were captured at the surface of bay and estuarine waters, ensuring that the species involved are indeed found in such environments. It should be noted, however, that migrations in an open system might bring new interactions. The reduction of turbulence in corrals relative to that of the surrounding water column may moderately decrease encounters. However, decreased turbulence may also make prey capture easier (Lewis \& Pedley 2001), potentially offsetting low predation due to decreased encounters. To acknowledge another problem, corrals excluded larger, filter-feeding predators (e.g. fish schools and large jellies), which have the potential to heavily impact larval populations in localized feeding areas. To our knowledge, corrals did not include assemblages or patches sampled from within a front, although assemblages were certainly variable due to small-scale patchiness (see Table 4). In nature, predators and prey may be concentrated together at elevated densities in convergences and fronts. However, the highest published field densities (e.g. Carriker 1951, Zimmerman 1972, Cameron \& Rumrill 1982, Rumrill et al. 1985, Emlet 1986, Miller 1995) do not approach those required in the current study and laboratory studies to elicit the predator responses (e.g. Rumrill et al. 1985, Pennington \& Chia 1984, Johnson \& Shanks 1997, Johnson \& Brink 1998), especially with background plankton present. Another experimental condition, the $24 \mathrm{~h}$ time period, is a snapshot of mortality for the tested conditions and may reasonably be extrapolated to longer larval periods for purposes of discussion. It should be noted, however, that different developmental stages may suffer differential predation with the same predators (Rumrill et al. 1985) and reliable long-term predation statistics require knowledge of risk at different embryological and larval stages.

Our observations of low and absent predation may be most directly applied to the predator-prey combinations in corrals. The possibility of the water column being a relative haven for certain larval types should be discussed in the light of these results, but untested predators may be major threats. To eliminate these uncertainties, studies should ideally scrutinize predation in an open planktonic system for the entire natural larval duration. However, it is currently not possible to study a natural, open population with the precision and detail gained by using corrals and marked larvae. With these techniques, we retained many of the benefits of laboratory-like manipulation while observing a captured natural assemblage. Since the goal of observational runs was the simple determination of predation rates and predator identities, the only experimental control needed would be for marked larval recovery 
(i.e. recovery in the absence of any predators). However, since the recovery was always $>96 \%$, and often $100 \%$, larval fates are known and recovery controls are unnecessary. In the 5 cases where larval recovery was $100 \%$ with zero variance, the fate of larvae may be unequivocally reported.

Perhaps the most compelling argument against predation artifacts in our corrals is the fact that the predators tested often feed on larvae under unnatural conditions, but do not consume them in corrals. It is most parsimonious to assume that, as conditions are made more natural, predation in corrals will more closely reflect nature than predation observed in small laboratory containers.

\section{Implications for life-history evolution}

Theory suggests that the evolution of marine invertebrate life histories is influenced by planktonic mortality rates. High planktonic mortality is thought to drive selection for short planktonic duration and lecithotrophy; low planktonic mortality should result in selection for longer planktonic periods and planktotrophy (Vance 1973, Strathmann 1977). Evolution of larval trophic mode tends to progress from planktotrophy to lecithotrophy (Strathmann 1974, 1978a,b, Emlet et al. 1987, Pechenik 1999). High planktonic mortality rates, of which predation is generally presumed to be a major source (reviews by Young \& Chia 1987, Rumrill 1990, Morgan 1995), have been invoked as the driving mechanism for this evolutionary trend (Vance 1973, Strathmann 1977, Emlet et al. 1987, Rumrill 1990, Pechenik 1999). Our evidence suggests that there can be periods when planktonic predation is low (i.e. those periods when the natural assemblages are similar to those captured in our corrals). Actual predators should be confirmed for any larval type before speculation is made about larval predation as a major source of planktonic mortality and, thus, a driving force for selection. In the absence of other factors, low planktonic predation would allow populations to experience relatively unfettered selection for the potential advantages of an extended planktonic life.

\section{CONCLUSIONS}

In conclusion, we observed predation of invertebrate larvae in near-natural plankton assemblages using in situ corrals. In most replicated runs we found no predation on larvae. In the presence of Proboscidactyla flavicirrata and Noctiluca scintillans, predation on marked bivalve veligers ranged from limited to high. However, in only 2 of 6 runs where N. scintillans were present did they prey on larvae. Wild bivalve veligers, captured with the natural plankton assemblages, were found in the guts of 4 types of coelenterate predators, but predation rates were low. These coelenterates also preyed on wild nauplii and polychaete metatrochophores. While larvae may or may not be an important dietary component for these coelenterates, these data suggest that they do not greatly reduce larval populations. While there may be water masses or time periods where larvae are safe, the appearance of a particular predator, such as N. scintillans in our corrals, can boost predation risk. Obviously, there are many potential predators that were not present in corrals. Corral assemblages did, however, include a wide range of potential predators over diverse replicated circumstances. It may frequently be the case that larval populations suffer little or no intraplanktonic predation.

Acknowledgements. W. Bradshaw, S. Rumrill, L. Shapiro, and C. Whitlock provided helpful input on this manuscript, as did anonymous reviewers. Corrals were constructed by W. Young at Aquatic Research Instruments. J. Thompson assisted with Coos Bay corral deployment. B. Pernet provided cultured polynoid larvae. J. Hoffman procured adult sand dollars for spawning. Whiskey Creek Oyster Farms supplied oyster veligers. C. Johnson provided invaluable input and logistical support. Special thanks to the Oregon Institute of Marine Biology and Friday Harbor Laboratories. This research was supported by a grant from the National Science Foundation (OCE-9521093) and a Lerner-Gray award from the American Museum of Natural History.

\section{LITERATURE CITED}

Alvarez-Cadena JN (1993) Feeding of the chaetognath Sagitta elegans Verrill. Estuar Coast Shelf Sci 36:195-206

Ayers JC (1956) Population dynamics of the marine clam, Mya arenaria. Limnol Oceanogr 1:26-34

Bailey JE, Wing BL, Mattson CR (1975) Zooplankton abundance and feeding habits of fry of pink salmon, Oncorhynchus gorbuscha, and chum salmon, Oncorhynchus keta, in Traitors Cove, Alaska, with speculations on the carrying capacity of the area. Fish Bull (Washington DC) 73:846-861

Bailey KM, Yen J (1983) Predation by a carnivorous marine copepod, Euchaeta elongata Esterly, on eggs and larvae of the Pacific hake, Merluccius productus. J Plankton Res 5: $71-82$

Cameron RA, Rumrill SS (1982) Larval abundance and recruitment of the sand dollar Dendraster excentricus in Monterey Bay, California, USA. Mar Biol 71:197-202

Carriker MR (1951) Ecological observations on the distribution of oyster larvae in New Jersey estuaries. Ecol Monogr 21:19-38

Chandy ST, Greene CH (1995) Estimating the predatory impact of gelatinous zooplankton. Limnol Oceanogr 40: 947-955

Chia FS, Walker CW (1991) Echinodermata: Asteroidea. In: Giese AC, Pearse JS, Pearse VB (eds) Reproduction of marine invertebrates, Vol 6. Echinoderms and lophophorates. Boxwood Press, Pacific Grove, CA, p 301-353 Cowan JH Jr, Houde ED (1993) Relative predation potentials 
of scyphomedusae, ctenophores and planktivorous fish on ichthyoplankton in Chesapeake Bay. Mar Ecol Prog Ser 95:55-65

Cripps GC, Hill HJ (1998) Changes in lipid composition of copepods and Euphausia superba associated with diet and environmental conditions in the marginal ice zone, Bellingshausen Sea, Antarctica. Deep-Sea Res Part I Oceanogr Res Pap 45:1357-1381

Cronin T, Forward RB (1980) Effects of starvation on phototaxis and swimming of larvae of the crab Rhithropanopeus harrisii. Biol Bull (Woods Hole) 158:283-294

DeMott WR, Watson MD (1991) Remote detection of algae by copepods: Responses to algal size, odors and motility. J Plankton Res 13:1203-1222

Duong CK (1985) Feeding, mouthpart morphology, and swimming behavior in omnivorous calanoid copepods. PhD thesis, University of Toronto

Emery AR (1973) Comparative ecology and functional osteology of fourteen species of damselfish (Pisces: Pomacentridae) at Alligator Reef, Florida Keys. Bull Mar Sci 23: 649-770

Emlet RB (1986) Larval production, dispersal, and growth in a fjord: a case study on larvae of the sand dollar Dendraster excentricus. Mar Ecol Prog Ser 31:245-254

Emlet RB, McEdward LR, Strathmann RR (1987) Echinoderm larval ecology viewed from the egg. Echinoderm Stud 2: 55-136

Enomoto Y (1956) On the occurrence and the food of Noctiluca scintillans (Macartney) in the waters adjacent to the west coast of Kyushu, with special reference to the possibility of the damage caused to fish eggs by that plankton. Bull Jpn Soc Sci Fish 22:82-89

Feigenbaum D, Reeve MR (1977) Prey detection in the Chaetognatha: Response to a vibrating probe and experimental determination of attack distance in large aquaria. Limnol Oceanogr 22:1052-1058

Forward RB Jr, Cronin TW (1980) Tidal rhythms of activity and phototaxis of an estuarine crab larva. Biol Bull (Woods Hole) 158:295-303

Gaines S, Brown S, Roughgarden J (1985) Spatial variation in larval concentrations as a cause of variation in settlement for the barnacle, Balanus glandula. Oecologia 67: 267-272

Galtsoff PS (1964) The American oyster Crassostrea virginica Gmelin. Fish Bull (Wash DC) 64:1-480

Gerritsen J, Strickler JR (1977) Encounter probabilities and community structure in zooplankton: a mathematical model. J Fish Res Board Can 34:73-82

Gibb JA (1962) Tinbergen's hypothesis of the role of specific search images. Ibis 104:106-111

Goswami SC (1977) Development and predation in a calanoid copepod Tortanus forcipatus (Giesbrecht). Indian J Mar Sci 6:54-159

Graeve M, Hagen W, Kattner G (1994) Herbivorous or omnivorous? On the significance of lipid compositions as trophic markers in Antarctic copepods. Deep-Sea Res Part I Oceanogr Res Pap 41:915-924

Greene CH (1985) Planktivore functional groups and patterns of prey selection in pelagic communities. J Plankton Res 7 : 35-40

Greene CH (1988) Foraging tactics and prey-selection patterns of omnivorous and carnivorous calanoid copepods. Hydrobiologia 167:295-302

Greene CH, Landry MR (1988) Carnivorous suspension feeding by the subarctic calanoid copepod Neocalanus cristatus. Can J Fish Aquat Sci 45:1069-1074

Hansen B, Hansen PJ, Nielsen TG (1991) Effects of large non- grazable particles on clearance and swimming behaviour of zooplankton. J Exp Mar Biol Ecol 153:257-269

Hattori S (1962) Predatory activity of Noctiluca on anchovy eggs. Bull Tokai Reg Fish Res Lab 9:211-220

Hidu H, Haskin HH (1978) Swimming speeds of oyster larvae Crassostrea virginica in different salinities and temperatures. Estuaries 1:252-255

Hirota J (1974) Quantitative natural history of Pleurobrachia bachei in La Jolla Bight. Fish Bull (Wash DC) 72:295-335

Hobson ES, Chess JR (1976) Trophic interactions among fishes and zooplankters near shore at Santa Catalina island, California. Fish Bull (Wash DC) 74:567-598

Hobson ES, Chess JR (1978) Trophic relationships among fishes and plankton in the lagoon at Enewetak Atoll, Marshall Islands. Fish Bull (Wash DC) 76:133-153

Horridge GA, Boulton PS (1967) Prey detection by Chaetognatha via a vibration sense. Proc R Soc Lond Ser B Biol Sci 168:413-419

Johnson KB, Brink LA (1998) Predation on bivalve veligers by polychaete larvae. Biol Bull (Woods Hole) 194:297-303

Johnson KB, Shanks AL (1997) The importance of prey densities and background plankton in studies of predation on invertebrate larvae. Mar Ecol Prog Ser 158:293-296

Jørgensen CB (1981) Mortality, growth, and grazing impact of a cohort of bivalve larvae, Mytilus edulis L. Ophelia 20: 185-192

Kiørboe T, Titelman J (1998) Feeding, prey selection and prey encounter mechanisms in the heterotrophic dinoflagellate Noctiluca scintillans. J Plankton Res 20:1615-1636

Knudsen JW (1960) Reproduction, life history and larval ecology of the California Xanthidae, the pebble crabs. Pac Sci 14:3-17

Konstantinova MI (1966) Characteristics of movement of pelagic larvae of marine invertebrates. Dokl Akad Nauk SSSR 170:726-729

Konstantinova MI (1969) Movement of polychaete larvae. Dokl Akad Nauk SSSR 188:942-945

LaBarbera M (1974) Calcification of the first larval shell of Tridacna squamosa (Tridacnidae: Bivalvia). Mar Biol 25: $233-238$

Larson RJ (1991) Diet, prey selection and daily ration of Stomolophus meleagris, a filter-feeding Scyphomedusa from the NE Gulf of Mexico. Estuar Coast Shelf Sci 32:511-525

Latz MI, Forward RB Jr (1977) The effect of salinity upon phototaxis and geotaxis in a larval crustacean. Biol Bull (Woods Hole) 153:163-179

Lewis DM, Pedley TJ (2001) The influence of turbulence on plankton predation strategies. J Theor Biol 210:347-365

Lonsdale DJ, Heinle DR, Siegfried C (1979) Carnivorous feeding behavior of the adult calanoid copepod Acartia tonsa Dana. J Exp Mar Biol Ecol 36:235-248

Metz C, Shnack-Schiel SB (1995) Observations on carnivorous feeding in Antarctic calanoid copepods. Mar Ecol Prog Ser 129:71-75

Miller B (1995) Larval abundance and early juvenile recruitment of echinoids, asteroids, and holothuroids on the Oregon coast. Masters thesis, University of Oregon, Eugene

Morgan SG (1995) Life and death in the plankton: larval mortality and adaptation. In: McEdward LR (ed) Ecology of marine invertebrate larvae. CRC Press, Boca Raton, FL, p 279-322

Morris RH, Abbott DP, Haderlie E (1980) Intertidal invertebrates of California. Stanford University Press, Stanford

Nelson TC (1925) On the occurrence and food habits of ctenophores in New Jersey inland coastal waters. Biol Bull (Woods Hole) 48:92-111

Pearre SJ (1982) Estimating prey preference by predators: 
uses of various indices, and a proposal of another based on $\chi^{2}$. Can J Fish Aquat Sci 39:914-923

Pechenik JA (1999) On the advantages and disadvantages of larval stages in benthic marine invertebrate life cycles. Mar Ecol Prog Ser 177:269-297

Pennington JT (1985) The ecology of fertilization of echinoid eggs: The consequences of sperm dilution, adult aggregation, and synchronous spawning. Biol Bull (Woods Hole) 169:417-430

Pennington JT, Chia FS (1984) Morphological and behavioral defenses of trochophore larvae of Sabellaria cementarium (Polychaeta) against four planktonic predators. Biol Bull (Woods Hole) 167:168-175

Pennington JT, Rumrill SS, Chia FS (1986) Stage-specific predation upon embryos and larvae of the pacific sand dollar, Dendraster excentricus, by 11 species of common zooplanktonic predators. Bull Mar Sci 39:234-240

Perron FE (1986) Life history consequences of differences in developmental mode among gastropods in the genus Conus. Bull Mar Sci 39:485-497

Phillips NE, Pernet B (1996) Capture of large particles by suspension-feeding scaleworm larvae (Polychaeta: Polynoidae). Biol Bull (Woods Hole) 191:199-208

Prasad RR (1958) A note on the occurrence and feeding habits of Noctiluca and their effects on the plankton community and fisheries. Proc Indian Acad Sci Sect B 67:331-337

Purcell JE (1981) Selective predation and caloric consumption by the siphonophore Rosacea cymbiformis in nature. Mar Biol 63:283-294

Purcell JE, Mills CE (1988) The correlation between nematocyst types and diets in pelagic Hydrozoa. In: Hessinger DA, Lenhoff HM (eds) The biology of nematocysts. Academic Press, Berkeley, p 463-485

Purcell JE, Cresswell FP, Cargo DG, Kennedy VS (1991) Differential ingestion and digestion of bivalve larvae by the scyphozoan Chrysaora quinquecirrha and the ctenophore Mnemiopsis leidyi. Biol Bull (Woods Hole) 180: 103-111

Purcell JE, White JR, Roman MR (1994) Predation by gelatinous zooplankton and resource limitation as potential controls of Acartia tonsa copepod populations in Chesapeake Bay. Limnol Oceanogr 39:263-278

Quayle DB (1964) Distribution of introduced marine molluscs in British Columbia waters. J Fish Res Board Can 21: 1155-1181

Reeve MR (1980) Comparative experimental studies on the feeding of chaetognaths and ctenophores. J Plankton Res 2:381-393

Reeve MR (1981) Large cod-end reservoirs as an aid to the live collection of delicate zooplankton. Limnol Oceanogr 26:577-580

Rumrill SS (1990) Natural mortality of marine invertebrate larvae. Ophelia 32:163-198

Rumrill SS, Pennington JT, Chia FS (1985) Differential susceptibility of marine invertebrate larvae: Laboratory predation of sand dollar, Dendraster excentricus (Eschscholtz), embryos and larvae by zoeae of the red crab, Cancer productus Randall. J Exp Mar Biol Ecol 90: 193-208

Sastry AN (1985) Pelagic larvae: an evolutionary compromise. Maritimes 29:10-12

Strathmann M (1987) Reproduction and development of

Editorial responsibility: Lisa Levin (Contributing Editor),

La Jolla, California, USA marine invertebrates of the northern Pacific coast. University of Washington Press, Seattle

Strathmann RR (1974) The spread of sibling larvae of sedentary marine invertebrates. Am Nat 108:29-44

Strathmann RR (1977) Egg size larval development, and juvenile size in benthic marine invertebrates. Am Nat 111: 313-376

Strathmann RR (1978a) The evolution and loss of feeding larval stages of marine invertebrates. Evolution 32:894-906

Strathmann RR (1978b) Progressive vacating of adaptive types during the Phanerozoic. Evolution 32:907-914

Strathmann RR (1985) Feeding and nonfeeding larval development and life-history evolution in marine invertebrates. Annu Rev Ecol Syst 16:339-361

Sulkin SD (1973) Depth regulation of crab larvae in the absence of light. J Exp Mar Biol Ecol 13:73-82

Sulkin SD (1975) The influence of light in the depth regulation of crab larvae. Biol Bull (Woods Hole) 148:333-343

Thorson G (1950) Reproductive and larval ecology of marine bottom invertebrates. Biol Rev 25:1-45

Tinbergen L (1960) The natural control of insects in pinewoods 1: Factors influencing the intensity of predation by songbirds. Arch Néerl Zool 13:266-336

Tiselius P (1988) Effects of diurnal feeding rhythms, species composition and vertical migration on the grazing impact of calanoid copepods in the Skagerrak and Kattegat. Ophelia 28:215-230

Toonen RJ, Chia FS (1993) Limitations of laboratory assessments of coelenterate predation: Container effects on the prey selection of the Limnomedusa, Proboscidactyla flavicirrata (Brandt). J Exp Mar Biol Ecol 167:215-235

Turner JT (1984) The feeding ecology of some zooplankters that are important prey items of larval fish. NOAA Tech Rep NMFS 7:1-28

Vance RR (1973) On reproductive strategies in marine benthic invertebrates. Am Nat 107:339-352

Vanderploeg HA, Cavaletto JF, Liebig JR, Gardner WS (1998) Limnocalanus macrurus (Copepoda: Calanoida) retains a marine arctic lipid and life cycle strategy in Lake Michigan. J Plankton Res 20:1581-1597

Vega MPA (1997) The functional response of copepodid stages to adult of Parabroteas sarsi (Copepoda, Calanoida). Int Rev Gesamt Hydrobiol 82:95-105

Ward P, Shreeve RS, Cripps GC (1996) Rhincalanus gigas and Calanus simillimus: Lipid storage patterns of two species of copepod in the seasonally ice-free zone of the Southern Ocean. J Plankton Res 18:1439-1454

Yen J (1987) Predation by a carnivorous marine copepod, Euchaeta norvegica Boeck, on eggs and larvae of the North Atlantic cod Gadus morhua L. J Exp Mar Biol Ecol 112:283-296

Yen J, Nicoll NT (1990) Setal array on the first antennae of a carnivorous marine copepod, Euchaeta norvegica. J Crustac Biol 10:218-224

Young CM, Chia FS (1987) Abundance and distribution of pelagic larvae as influenced by predation, behavior, and hydrographic factors. In: Giese AC, Pearse JS (eds) Reproduction of marine invertebrates, Vol 9. Academic Press, New York, p 385-463

Zimmerman ST (1972) Seasonal succession of zooplankton populations in two dissimilar marine embayments on the Oregon coast. $\mathrm{PhD}$ thesis, Oregon State University, Corvallis

Submitted: November 5, 2001; Accepted: August 16, 2002

Proofs received from author(s): January 21, 2003 